\title{
Towards Liberal Education Assessment In Engineering And Technology Programs
}

Tom A. Eppes, University of Hartford, USA

Ivana Milanovic, University of Hartford, USA

Fredrick Sweitzer, University of Hartford, USA

\begin{abstract}
Our regional accrediting body, New England Association of Schools and Colleges, requires outcome assessment of core liberal education outcomes. Because of this mandate, and our new mission at the University to prepare students with the knowledge, skills, and values necessary to thrive and be engaged in a pluralistic, complex world, we have undertaken a project to develop and assess core liberal education outcomes. This paper describes the planning and actions taken to meet these new requirements in our engineering and technology programs. The college has expanded outcome assessment by including five "intellectual and practical skills," specifically, critical and creative thinking, inquiry/analysis, problem-solving, and information literacy. VALUE rubrics are being incorporated into the process to ascertain the best opportunities to measure student achievement within the engineering and technology programs. An assessment framework is presented and pilot results are discussed.
\end{abstract}

Keywords: Engineering; Technology; Liberal Education; Outcome Assessment; Engineering Education; NEASC; EAC; ABET

\section{THE CHALLENGE}

ew England Association of Schools and Colleges (NEASC), our accreditation body, requires
assessment of core liberal education outcomes. Undergraduates must demonstrate competence in
written and oral communication; the ability for scientific and quantitative reasoning, critical analysis and logical thinking; and the capability for continuing learning, including information literacy (NEASC, 2006). The university aspires to promote and integrate excellence in liberal and professional education. We have undertaken a project to identify a series of undergraduate learning outcomes to be addressed and assessed both in general education and in the majors. Learning experiences related to these outcomes foster the development of knowledge, skills, and habits of mind critical to meeting the demands of the workplace and functioning as contributing citizens in society (Bok, 2006; Humphreys, 2010; Arum \& Roksa, 2011). Nine intellectual and practical skills have been selected: oral/written communication, quantitative reasoning, critical and creative thinking, inquiry/analysis, problem-solving, teamwork, and information literacy. In our college, programs are currently accredited by the Accreditation Board for Engineering and Technology (ABET). ABET standards require assessment of four skills, namely oral/written communication, quantitative reasoning and teamwork are already being assessed. For the other five skills beyond ABET requirements the college has no process in place to formally measure student achievement. This essay describes the planning and activities undertaken to meet accreditation requirements along with preliminary findings from a recent pilot.

The university is a private institution with about 7,200 students of which 950 are enrolled in engineering (E) and engineering technology (ET) programs. Bachelor of Science degrees, accredited by the Engineering Accreditation Commission (EAC) of ABET, are offered in 6 majors: acoustical engineering \& music (new), biomedical, civil, computer, electrical and mechanical engineering. Within the last ten years, three of the programs were accredited for the first time. Undergraduate ET programs, accredited by the Technology Accreditation Commission (TAC) of ABET, include, electronic and mechanical engineering technology. Eleven E and ET programs, as well as a Masters program, are administered by four departments with a combined fulltime faculty of 38. 
Within E and ET programs, there is a fine balance between courses preparing students for the specific technical demands of the profession and non-technical courses that belong to the category of general education. Our four year programs have a relatively narrow range of credit hours (125 to 135); an increase in one area must be offset by a decrease in another. Our program constituents review each plan of study annually to identify needed changes.

The current outcome assessment process for E and ET programs is designed to meet the requisite ABET Criteria 3 (a-k) requirements. Evaluation is concentrated on third and fourth year courses and measures performance in specific embedded assignments within the core area, i.e. assignments are selected to be the most relevant to the major and are taught within the college. Core engineering and technology courses may be classified as one of the following five types:

- $\quad$ Theoretical -3 or 4 credits, largely lecture-based, and devoted to an advanced topic within a specific discipline such as thermodynamics or wireless communications.

- $\quad$ Experiential - Laboratory-oriented course equivalent to 1 to 3 credits.

- $\quad$ Professional - Included for all E majors and covering topics common to disciplines. Currently, ET programs do not have a professional component.

- $\quad$ Capstone - An integrating experience of 3 to 6 credits, taken in the final year of study in which the student completes an unscripted design project.

- $\quad$ Other - A three course technical communication sequence focused on written and oral skills taken by all ET majors.

\section{EDUCATIONAL CONTEXT}

The changes being mandated by NEASC are part of a much larger policy initiative that is national in scope. Regional accreditation boards are undertaking similar efforts in their respective areas of authority. Over the last decade, concern over the quality of higher education in the United States (U.S.) has been widely expressed and debated. Faced with mounting evidence that the U.S. no longer lead the world in postsecondary achievement, educational proponents have advocated far-reaching efforts to increase the number and quality of higher education graduates (Association of American Colleges and Universities [AACU], 2002; U.S. Department of Education Commission on the Future of Higher Education, 2006; AACU Board of Directors, 2010).

The Association of American Colleges and Universities (AACU, 2010), representing over 1,100 institutions of all types and sizes, and whose sole focus is the quality of learning, asserted a fundamental question: "What do college students need to learn and be able to do?" The AACU (2005) launched an initiative, Liberal Education and America's Promise (LEAP): Excellence for Everyone as a Nation Goes to College. LEAP challenges schools, colleges, and universities to fulfill the promise of liberal education in a "new century marked by increasing global complexity, interconnectedness and rapid change." LEAP ${ }^{1}$ recommends that students acquire the following four blocks of essential learning abilities:

- Knowledge of human cultures and the world through the study of natural and social sciences, mathematics, humanities, histories, languages and the arts.

- Intellectual and practical skills: inquiry/analysis, critical and creative thinking, written and oral communication, quantitative reasoning, information literacy, teamwork and problem solving.

- $\quad$ Personal and social responsibility spanning civic knowledge and engagement (local and global), intercultural knowledge and competence, ethical reasoning and action, foundations and skills for lifelong learning.

- $\quad$ Integrative and applied learning including synthesis and advanced accomplishment across general and specialized studies.

\footnotetext{
${ }^{1}$ For more information, please visit www.aacu.org/leap/vision.cfm 
Secretary of Education, Margaret Spellings, announced in 2005 the formation of the Commission on the Future of Higher Education and charged it with developing a comprehensive national strategy for postsecondary education. The Commission (U.S. Department of Education, 2006) issued a report, A Test of Leadership: Charting the Future of U.S. Higher Education. One finding noted that the quality of student learning at U.S. colleges and universities is inadequate and, in some cases, declining. Shortcomings were found in learning outcomes and core literacy skills. The process to assess learning outcomes is complicated because program completion and higher-level achievement are not one and the same (Bok, 2006; AACU, 2008). This returns us to the question in 2007 by the AACU: "What do college students need to learn and be able to do?" On an international scale, the Organization for Economic Co-operation and Development (OECD, 2008) provided a perspective on current practices in standardized assessment across five countries and proposed a typology of higher education learning outcomes.

Improving the performance of post-secondary institutions has increasingly taken center stage in U.S. economic recovery plans. In remarks by President Barack Obama (2011) on the American Graduation Initiative, a top priority is to ensure that the U.S. has the highest percentage of college-educated workers in the world. However, to make excellence truly inclusive, quality must drive commitment to college completion (U.S. Department of Education, 2006).

The implications of LEAP on the engineering and technology higher education community leads to the following question: What is the purpose of liberal education and how should it permeate our curricula? Newman's approach (1947) to liberal education is that of "enlargement or expansion of the mind," a process in which university education helps students develop skills necessary for intellectual expansion. Heywood (2010) introduced the idea of engineering literacy being a component of liberal knowledge as defined by Newman. Harper, Lattuca, Yin, and Terenzuini (2010) conducted a survey of engineering administrators and found substantial support for integrating the goals of liberal and professional education. They concluded that administrators view liberal learning as a path to prepare students to become productive professionals, community citizens, and leaders in a diverse and socially dynamic world. Further, there is ample evidence that liberal learning outcomes are most effectively achieved when undertaken as a partnership between the often separated curricular spheres of general education and the major (Valenzuela, Allen, \& Swenty, 2008).

\section{INCREMENTAL ASSESSMENT REQUIREMENTS}

Given this broad educational context that involves both public and private initiatives, we now examine the new requirements by NEASC which equate to the nine skills specified in the "intellectual and practical" LEAP block described previously. Four of the aforementioned nine skills are currently being assessed with no process in place for the following five skills: inquiry/analysis, critical thinking, creative thinking, information literacy, and problem solving.

Oral and written communications along with teamwork are periodically assessed to satisfy ABET requirements. These three abilities have long been identified as important for E and ET graduates and are strongly endorsed by employers. A variety of assignments and assessment tools have been created to both promote development and measure achievement. Additionally, the task of assessing quantitative reasoning appears straightforward given the high level of mathematical content in core E and ET courses.

Our efforts are centered on inquiry/analysis, critical and creative thinking, information literacy, and problem solving as defined in Table 1. These five skills pose an outcome assessment challenge because faculty members who teach upper-level courses do not explicitly measure achievement level in these five skills. In addition, current assignments are not designed to do so. As a result, course and curricular changes will be necessary.

Part of LEAP was the development of a set of rubrics called Valid Assessment of Learning in Undergraduate Education (VALUE, 2010; Rhodes, 2010). These rubrics are intended for institutional-level use in evaluating and discussing student learning within a basic framework of expectations. Consequently, each of the "intellectual and practical skills" defined in Table 1 have an associated VALUE rubric which are helpful in two ways. First, we were able to determine if our methodologies could be improved by switching to a new rubric. Second, the VALUE rubrics enable quick implementation. 
Table 1. Skill definitions (VALUE, 2010)

\begin{tabular}{|l|l|}
\hline Intellectual and Practical Skills & \multicolumn{1}{c|}{ Definition } \\
\hline Inquiry and Analysis (IA) & $\begin{array}{l}\text { Systematic process of exploring issues, objects or works through the collection \& analysis of } \\
\text { evidence that results in informed conclusions or judgments. Analysis is the process of } \\
\text { breaking complex topics or issues into parts to gain a better understanding of them. }\end{array}$ \\
\hline $\begin{array}{l}\text { Critical Thinking } \\
\text { (CT) }\end{array}$ & $\begin{array}{l}\text { Habit of mind characterized by the comprehensive exploration of issues, ideas, artifacts, \& } \\
\text { events before accepting or formulating an opinion or conclusion. }\end{array}$ \\
\hline $\begin{array}{l}\text { Creative Thinking } \\
\text { (C) }\end{array}$ & $\begin{array}{l}\text { Both the capacity to combine or synthesize existing ideas, images, or expertise in original } \\
\text { ways and the experience of thinking, reacting, \& working in an imaginative way } \\
\text { characterized by a high degree of innovation, divergent thinking, \& risk taking. }\end{array}$ \\
\hline $\begin{array}{l}\text { Information Literacy } \\
\text { (IL) }\end{array}$ & $\begin{array}{l}\text { Ability to know when there is a need for information, be able to identify, locate, evaluate, \& } \\
\text { effectively \& responsibly use \& share that information for the problem at hand. }\end{array}$ \\
\hline $\begin{array}{l}\text { Problem Solving } \\
\text { (PS) }\end{array}$ & $\begin{array}{l}\text { Process of designing, evaluating \& implementing a strategy to answer an open-ended } \\
\text { question or achieve a desired goal. }\end{array}$ \\
\hline
\end{tabular}

Armed with the skill descriptions in Table 1 and after examining the various core courses across the curricula, we discovered that there are ample assessment possibilities. Table 2 shows some of the more suitable areas as a function of course type. The professional and experiential courses present the greatest opportunity to absorb the new accreditation skill requirements. The capstone course which entails a rigorous and open-ended design project warranted more consideration. Both E and ET capstones consist of five largely sequential activities that yield a diverse array of assignments enabling all five liberal education skills to be measured. Table 2 shows the potential for skill assessment within each of these capstone portions. It should be noted that the capstone is currently a primary source of outcome results for ABET accreditation leading to a concern that it might become overloaded with assessment.

Table 2. Assessment opportunities in core courses

\begin{tabular}{|c|c|c|c|c|c|}
\hline Course Type & IA & CT & $\mathbf{C}$ & IL & PS \\
\hline Professional (E only) & $\checkmark$ & $\checkmark$ & & $\checkmark$ & $\checkmark$ \\
\hline Experiential & $\checkmark$ & $\checkmark$ & $\checkmark$ & $\checkmark$ & $\checkmark$ \\
\hline Theoretical & $\checkmark$ & & & & $\checkmark$ \\
\hline Other (ET only) & $\checkmark$ & & & $\checkmark$ & \\
\hline Capstone Activity & $\checkmark$ & $\checkmark$ & $\checkmark$ & $\checkmark$ & $\checkmark$ \\
\hline (1) Proposal & $\checkmark$ & & $\checkmark$ & $\checkmark$ & \\
\hline (2) Design Elements & $\checkmark$ & $\checkmark$ & $\checkmark$ & & \\
\hline (3) Detailed Design & & $\checkmark$ & & & $\checkmark$ \\
\hline (4) Implementation & & & $\checkmark$ & & $\checkmark$ \\
\hline (5) Reporting Results & & & & $\checkmark$ & \\
\hline
\end{tabular}

\section{ASSESSMENT TOOLS AND PILOT RESULTS}

The VALUE rubrics, either as is or slightly modified, provide a convenient toolset for use in the five course types. These rubrics contain up to six specific attributes as illustrated in Table 3. A description of these attributes may be found on the rubric forms available online (VALUE, 2010).

Table 3. VALUE rubric attributes (VALUE, 2010)

\begin{tabular}{|l|l|l|l|l|}
\hline Inquiry and Analysis (IA) & Critical Thinking (CT) & Creative Thinking (C) & Information Literacy (IL) & Problem Solving (PS) \\
\hline Topic selection & Explanation of issues & Acquire competencies & $\begin{array}{l}\text { Extent of information } \\
\text { needed }\end{array}$ & Define problem \\
\hline $\begin{array}{l}\text { Existing knowledge, } \\
\text { research \& views }\end{array}$ & Evidence & Take risks & $\begin{array}{l}\text { Access needed } \\
\text { information }\end{array}$ & Identify strategies \\
\hline Design process & $\begin{array}{l}\text { Influence of context } \\
\& \text { assumptions }\end{array}$ & Solve problems & $\begin{array}{l}\text { Evaluate \& source } \\
\text { critically }\end{array}$ & $\begin{array}{l}\text { Propose solutions } \\
\text { \& hypotheses }\end{array}$ \\
\hline Analysis & $\begin{array}{l}\text { Perspective, thesis \& } \\
\text { hypothesis }\end{array}$ & Embrace contradictions & $\begin{array}{l}\text { Effectively use to } \\
\text { accomplish a purpose }\end{array}$ & $\begin{array}{l}\text { Evaluate potential } \\
\text { solutions }\end{array}$ \\
\hline Conclusions & $\begin{array}{l}\text { Conclusions \& } \\
\text { related outcomes }\end{array}$ & $\begin{array}{l}\text { Be innovative } \\
\text { Connect, synthesize } \\
\& \text { transform }\end{array}$ & $\begin{array}{l}\text { Access \& use ethically \& } \\
\text { legally }\end{array}$ & Implement solution \\
\hline Limitations \& implications & & Evaluate outcomes \\
\hline
\end{tabular}


Each VALUE rubric contains an achievement scale from 1 to 4 with commentary to guide the selection of the most appropriate result. To ascertain the degree of suitability as an assessment tool, we examined each rubric according to the following criteria:

- Extent to which the rubric attributes aligned with current course outcomes and evidence of student achievement,

- Ability of the faculty to consistently apply them,

- Applicability across E and ET curricula and course types.

We found the VALUE rubrics to be a good starting point for pilot assessment of the five targeted liberal education skills. Some customization will likely be needed for best results in engineering and technology courses. Based on the placement opportunities presented earlier in Table 2 and the need to avoid overloading the capstone, an assessment framework was developed. Table 4 shows how the five skills could be evaluated, each involving a minimum of two course types.

Table 4. Assessment framework for $\mathrm{E}$ and ET programs

\begin{tabular}{|c|c|c|c|c|c|}
\hline \multicolumn{6}{|c|}{ Engineering (E) Programs } \\
\hline Course Type & IA & PS & $\mathrm{CT}$ & IL & $\mathrm{C}$ \\
\hline Professional & & & $\checkmark$ & $\checkmark$ & \\
\hline Experiential & & $\checkmark$ & & & $\checkmark$ \\
\hline Theoretical & $\checkmark$ & $\checkmark$ & & & \\
\hline Capstone & $\checkmark$ & & $\checkmark$ & $\checkmark$ & $\checkmark$ \\
\hline \multicolumn{6}{|c|}{ Engineering Technology (ET) Programs } \\
\hline Course Type & IA & PS & $\mathrm{CT}$ & IL & $\mathrm{C}$ \\
\hline Professional & \multicolumn{5}{|c|}{ None } \\
\hline Experiential & & $\checkmark$ & $\checkmark$ & & $\checkmark$ \\
\hline Theoretical & $\checkmark$ & $\checkmark$ & & & \\
\hline Capstone & $\checkmark$ & & $\checkmark$ & $\checkmark$ & $\checkmark$ \\
\hline Other & & & & $\checkmark$ & \\
\hline
\end{tabular}

A pilot was performed that targeted three skills: creative thinking, critical thinking and problem solving. The planning was aided by Bommarju, Earley, and Hergert (2003) who described some of the challenges that faculty face in assessing liberal education concepts. Lansari, Al-Rawi, Tubaishat, and Bouslama (2008) showed how the problem solving and critical thinking skills could be measured and incorporated into an information systems curriculum. Ralston and Bays (2010) discussed the relationship between critical thinking and ABET outcomes that led to specific rubrics being developed and validated. An internal curricular strategy, Improved Capstone (ICap), served as a valuable foundation (Eppes, Milanovic, \& Sweitzer, 2011). Starting in 2005, ICap was implemented in two ET programs whereby experiential courses sequentially introduce challenging and open-ended assignments that foster cognitive learning. ICap courses contain an assessment methodology that measures four of the "intellectual and practical" skills. One challenge that quickly came to light in planning a pilot was the availability of appropriate student work products in the capstone. None of the existing written documents seemed very useful to evaluate any of the three skill areas for the pilot. However, an interesting idea surfaced regarding the team status meetings with the instructor in which a Q\&A interview style could be used to gather sufficient evidence.

The pilot was conducted over two semesters in spring 2010 and again in spring 2011 involving the capstone for Electrical and Computer Engineering majors. Face-to-face meetings with the teams provided an excellent opportunity to evaluate the skill levels. The instructor reported that each team employed all three skills at one or more point(s) during the semester. The results are shown in Table 5 for all of the teams. Good performance was observed in many teams for each skill; however, the best teams were not always the same. No team demonstrated a low achievement level in any area; indicative of either the students or a lack of training on the part of the instructor. 
Table 5. Pilot assessment results

\begin{tabular}{|l|c|c|c|}
\hline \multicolumn{1}{|c|}{ Capstone Team } & $\begin{array}{c}\text { PS } \\
\text { (1-4 scale) }\end{array}$ & $\begin{array}{c}\text { CT } \\
\text { (1-4 scale) }\end{array}$ & C \\
\hline (1) Bluetooth FM transmitter & 3.8 & 3.8 & 3.3 \\
\hline (2) Neural network pump reliability & 4.0 & 4.0 & 3.6 \\
\hline (3) Wireless super-heterodyne radio & 3.3 & 2.8 & 3.1 \\
\hline (4) Wireless power transfer & 3.1 & 3.1 & 3.6 \\
\hline (5) Autonomous fire-fighting robot & 3.6 & 2.8 & 3.1 \\
\hline (6) Microwave electromagnetic curing & 3.3 & 3.6 & 3.1 \\
\hline (7) Unmanned aerial vehicle & 3.7 & 3.8 & 3.6 \\
\hline (8) Principles of Balance control & 3.5 & 3.7 & 3.3 \\
\hline (9) Movable solar panel & 3.6 & 3.7 & 3.7 \\
\hline (10) Solar energy recovery & 2.5 & 2.8 & 3.0 \\
\hline (11) Prediction of limit cycles & 3.3 & 3.7 & 3.3 \\
\hline (12) The heat is on & 3.6 & 3.4 & 2.8 \\
\hline (13) Design of a sequenced system & 3.2 & 2.8 & 3.2 \\
\hline (14) Balance and coordination & 3.5 & 3.2 & 3.9 \\
\hline (15) Automotive engine control & 3.7 & 3.8 & 3.5 \\
\hline (16) Theremin design & 2.6 & 2.4 & 2.8 \\
\hline (17) Residential energy management & 2.5 & 2.4 & 3.1 \\
\hline (18) Software defined radio & 2.9 & 3.0 & 2.8 \\
\hline (19) Amplitude shift keying system & 3.3 & 3.9 & 3.3 \\
\hline Overall average & 3.3 & & \\
\hline
\end{tabular}

\section{CONCLUSION}

In response to mandates from NEASC, our new academic mission, and a desire to integrate liberal and professional education, we have undertaken efforts to identify core undergraduate learning outcomes to be addressed and assessed. Outcome assessment has been expanded to include five "intellectual and practical skills," specifically, critical/creative thinking, inquiry/analysis, problem-solving, and information literacy. A framework showing where the best opportunities to measure student achievement level within core courses is presented. A recent pilot, employing VALUE rubrics and targeting three of the five skills, was successful in identifying a method to observe and measure achievement. Additional pilots on assessment methods and their placement within the curriculum are planned.

\section{AUTHOR INFORMATION}

Tom A. Eppes is an Associate Professor of Electrical and Computer Engineering in the College of Engineering, Technology, and Architecture at the University of Hartford. He holds Bachelor and Master of Science degrees in Electrical Engineering from Texas A\&M University and a Ph.D. in Electrical Engineering from the University of Michigan. E-mail: eppes@hartford.edu. Corresponding author.

Ivana Milanovic is an Associate Professor of Mechanical Engineering in the College of Engineering, Technology, and Architecture at the University of Hartford. She received her Ph.D. in Mechanical Engineering from Polytechnic University, NY, and M.S. and B.S. from University of Belgrade in Yugoslavia. E-mail: milanovic@ hartford.edu

Fredrick Sweitzer is the Assistant Provost and Dean of Faculty Development in the Office of the Provost at the University of Hartford. He holds Ed.D. and M.Ed. degrees from the University of Massachusetts and a B.A. from the University of Pennsylvania. E-mail: sweitzer@hartford.edu

\section{REFERENCES}

1. Association of American Colleges and Universities. (2002). Greater Expectations: A New Vision for Learning as a Nation Goes to College. Washington, DC.

2. Association of American Colleges and Universities. (2005). Liberal Education and America's Promise (LEAP): Excellence for Everyone as a Nation Goes to College. Washington, DC. 
3. Association of American Colleges and Universities. (2007). College Learning for the New Global Century: A Report from the National Leadership Council for Liberal Education and America's Promise.

Washington, DC.

4. Association of American Colleges and Universities, Peter D. Hart Research Associates. (2008). How Should Colleges Assess and Improve Student Learning: Employers' Views on the Accountability Challenge. Washington, DC.

5. Association of American Colleges and Universities Board of Directors. (2010). The Quality Imperative: Match Ambitious Goals for College Attainment with an Ambitious Vision for Learning. Washington, DC.

6. Arum, R., \& Roksa, J. (2011). Academically Adrift: Limited Learning on College Campuses. University of Chicago Press, Chicago, IL.

7. Bok, D. (2006). Our Underachieving Colleges: A Candid Look at How Much Students Learn and Why They Should Be Learning More. Princeton University Press, Princeton, NJ.

8. Bommaraju, S., Earley, R. \& Hergert, D. (2003). Incorporating Liberal Education Concepts into Engineering Technology Senior Design Course. Proceedings of the ASEE National Conference and Exposition, Nashville, TN, Session 502.

9. Eppes, T., Milanovic, I. \& Sweitzer, F. (2011). Strengthening Capstone Skills in STEM Programs. Journal of Innovative Higher Education, 37(1).

10. Harper, B., Lattuca, L., Yin, A. \& Terenzuini, P. (2010). Liberal Education for the Engineer of 2020: Are Administrators on Board? Proceedings of the ASEE National Conference and Exposition, Louisville, KY, Paper AC 2010-1335.

11. Heywood, J. (2010). Engineering Literacy: A Component of Liberal Education. Proceedings of the ASEE National Conference and Exposition, Louisville, KY, Paper AC 2010-1505.

12. Humphreys, D. (2010). Making the Case for Liberal Education: Responding to Challenges. Association of American Colleges and Universities, Washington, DC.

13. Lansari, A., Al-Rawi, A., Tubaishat, A. \& Bouslama, F. (2008). A Course Sequence for Integrating Problem Solving and Critical Thinking in a Hybrid Outcome-Based IS/IT Curriculum. Proceedings of the ASEE National Conference and Exposition, Pittsburgh, PA, Paper AC 2008-1581.

14. New England Association for Schools and Colleges. (2006). Standards for Accreditation. Bedford, MA, 2006.

15. Newman, J. H. (1947). The Idea of a University, Longmans and Green, London, England. Organization for Economic Co-operation and Development (OECD) Directorate for Education, Nusche, D. (2008). Assessment of Learning Outcomes in Higher Education: A comparative Review of Selected Practices.

16. President Barack Obama. (2011). Remarks by the President on the American Graduation Initiative, http://www.whitehouse.gov/the_press_office/Remarks-by-the-President-on-theAmericanGraduationInitiative-in-Warren-MI/, Accessed March 1, 2011.

17. Ralston, P. \& Bays, C. (2010). Refining a Critical Thinking Rubric for Engineering. Proceedings of the ASEE National Conference and Exposition, Louisville, KY, Paper AC 2010-1518.

18. Rhodes, T. L. (2010). Assessing Outcomes and Improving Achievement: Tips and Tools for Using Rubrics. Association of American Colleges and Universities, Washington, DC.

19. Valenzuela, M., Allen, J. \& Swenty, B. (2008). Liberal Education: A Survey of Goals. Proceedings of the ASEE National Conference and Exposition, Pittsburgh, PA, Paper AC 2008-973.

20. VALUE Rubrics. (2010). http://www.aacu.org/VALUE/rubrics/index_p.cfm Retrieved December 28, 2010.

21. U.S. Department of Education, Commission on the Future of Higher Education. (2006). A Test of Leadership: Charting the Future of U.S. Higher Education. Washington, DC. 
NOTES 